\title{
Heart Rate Variability in Patients with Suspected or Confirmed Diagnosis of COVID-19: A Retrospective Analysis in Comparison to Healthy Controls and in Relation to Proinflammatory Cytokines
}

\section{(COVID-19 Şüpheli veya Kesin Tanısı Alan Hastalarda Kalp Hızı Değişkenliği: Sağlıklı Kontrollere Kıyasla ve Proinflamatuvar Sitokinler Açısından Bir Retrospektif Analiz)}

\author{
Dursun Topal ${ }^{1}$, Berat Uguz $^{1 *}$, Ismet Zengin ${ }^{1}$, Selvi Oztas ${ }^{1}$, Selma Kenar Tiryakioglu ${ }^{1}$ \\ ${ }^{1}$ Bursa City Hospital, Bursa, Turkey. \\ e-mail: dursuntopal@yahoo.com, beratuguz33@hotmail.com, ismetzengin48@hotmail.com, \\ selvi35byih@hotmail.com, selmatiryakioglu26@gmail.com, selmatiryaki@msn.com \\ ORCID: 0000-0001-7053-2131 \\ ORCID: 0000-0002-4834-5572 \\ ORCID: 0000-0003-0758-649X \\ ORCID: 0000-0002-0867-3264 \\ ORCID: 0000-0003-3443-6593 \\ *Sorumlu yazar/ Corresponding Author: Berat Uğuz \\ Gönderim Tarihi / Received: 15.08.2021 \\ Kabul Tarihi / Accepted: 20.08.2021 \\ DOI: $10.34087 /$ cbusbed.983215
}

\begin{abstract}
Öz
Giriş ve Amaç: $\mathrm{Bu}$ çalışma, Koronavirüs hastalığı-2019 (COVID-19) şüpheli veya kesin tanısı ile yatışı yapılan hastalarda kalp hızı değişkenliğinin (KHD) sağlıklı kontrollerle kıyaslanması ve proinflamatuvar sitokinler bağlamında değerlendirilmesi amacı ile tasarlandı.

Gereç ve Yöntemler: Bu çalışmaya, 3 alt gruptan oluşan (53 kesin COVID-19 tanısı almış hasta, 42 şüpheli COVID19 tanısı almış hasta ve 20 sağlıklı kontrol) toplam 115 denek dahil edildi. Hasta demografik özellikleri, inflamatuvar belirteçler (C-reaktif protein [CRP], D-Dimer, ferritin ve prokalsitonin) ve 24-saat Holter monitorizasyon parametrelerine ait veriler kaydedildi.

Bulgular: Holter monitorizayonu parametrelerinin hiçbiri, şüpheli ve kesin COVID-19 tanısına sahip gruplar arasında anlamlı fark göstermedi. Şüpheli ve kesin COVID-19 tanılı her iki grupta, bütün NN intervallerinin standart sapması (SDNN, her biri için $p<0,001$ ) ve KHD triangular indeksi (her biri için $p<0,001$ ) değerleri kontrol grubu değerlerine göre anlamlı olarak daha düşük iken, ardışık normal NN intervalleri arasındaki farkların karekökü (RMSSD, her biri için $\mathrm{p}<0,001$ ), düşük frekans (LF, sirasıyla $\mathrm{p}=0,001$ ve $\mathrm{p}<0.001$ ), yüksek frekans (HF, her biri için $\mathrm{p}<0,001) \mathrm{ve} L F / \mathrm{HF}$ oranı (her biri için $\mathrm{p}<0,001$ ) değerleri kontrol grubu değerlerine göre anlamlı olarak daha yüksek bulundu. Prokalsitonin ve SDNN değerleri arasında pozitif korelasyon mevcuttu $(r=0,227, p=0,044)$.

Sonuç: Bulgularımız COVID-19 hastalarında KHD'nin hem zaman-bağımlı hem de frekans-bağımlı parametreler açısından önemli değişimler gösterdiğine ve bu değişimin viral yükten bağımsız olup, otonom sinir sistemi disfonksiyonu lehine olduğuna işaret etmektedir. Dolayısıyla bulgularımız, KHD’nin COVID-19 hastalarında altta yatan inflamatuvar sürece veya tedavi yan etkilerine bağlı gelişen otonom disfonksiyonun değerlendirilmesi açısından kullanışı bir klinik araç olarak sitokin firtınasının erken tahmini, tiraj, hastalık progresyonunun izlenmesi ve tedavi bakımından klinisyenlere yol gösterebileceği yönündedir.
\end{abstract}

Anahtar kelimeler: COVID-19, Frekans-bağımlı indeksler, Kalp hızı değişkenliği, Kesin tanı, Proinflamatuvar sitokinler, Şüpheli tanı, Zaman-bağımlı indeksler. 
Objective: This study was designed to evaluate heart rate variability (HRV) in hospitalized patients with suspected or confirmed diagnosis of coronavirus disease-2019 (COVID-19) in comparison to healthy controls and in relation to proinflammatory cytokines.

Materials and Methods: A total of 115 subjects consisting of 3 subgroups (53 patients with confirmed diagnosis of COVID-19, 42 patients with suspected diagnosis of COVID-19 and 20 healthy controls) were included in this study. Data on patient demographics, inflammatory markers (C-reactive protein [CRP], D-Dimer, ferritin, procalcitonin) and the 24-h Holter monitoring parameters were recorded.

Results: None of the Holter monitoring parameters differed significantly between patients with suspected COVID-19 and those with confirmed COVID-19. In both suspected COVID-19 and confirmed COVID-19 groups, standard deviation of all NN intervals (SDNN, $\mathrm{p}<0.001$ for each) and HRV triangular index ( $<<0.001$ for each) values were significantly lower than the values in the control group, while the root mean square of differences between successive NN intervals (RMSSD, $\mathrm{p}<0.001$ for each), low frequency (LF, $\mathrm{p}=0.001$ and $\mathrm{p}<0.001$, respectively), high frequency (HF, $\mathrm{p}<0.001$ for each) and LF/HF ratio ( $<<0.001$ for each) values were significantly higher than the values in the control group. Procalcitonin and SDNN values $(\mathrm{r}=0.227, \mathrm{p}=0.044)$ were positively correlated.

Conclusion: Our findings revealed significant changes in both time-domain and frequency-domain parameters of HRV in COVID-19 patients, regardless of the viral load, in favor of autonomic nervous system dysfunction. Accordingly, our findings indicate the potential utility of HRV as a valuable clinical tool to monitor autonomic dysfunction in COVID-19 patients resulting from the underlying inflammatory process or the treatment side effects, aiding clinicians in early prediction of a cytokine storm, and in the triage, disease progress monitoring and treatment.

Keywords: COVID-19, heart rate variability, time domain indices, frequency-domain indices, suspected diagnosis, confirmed diagnosis, proinflammatory cytokines

\section{Introduction}

The coronavirus disease-2019 (COVID-19), an infectious disease caused by a novel severe coronavirus designated as acute respiratory syndrome coronavirus-2 (SARS-CoV-2), has become a global pandemic since its onset in Wuhan, China, at the end of $2019[1,2]$.

Although the disease affects predominantly the respiratory system, cardiac involvement is considered a possible late phenomenon with great concern in COVID19 as manifested in nearly up to one third of patients with myocardial injury, arrhythmias, cardiac arrest, heart failure and coagulation abnormality [3-6].

The first stage of viral replication is followed by the second stage of lung involvement with development of severe pneumonia and adult respiratory distress syndrome (ARDS) in COVID-19, and then the third stage appears involving a cytokine storm (increase in release of interleukin [IL-6], ferritin, C-reactive protein [CRP] or D-dimer), a large adrenergic release modulated by the sympathetic nervous system (SNS) and a compensatory anti-inflammatory response (CARS) modulated by the anti-inflammatory cholinergic pathway and the parasympathetic nervous system (PNS) [7-10].

Emerging at the third stage of the disease, the cardiovascular manifestations have been associated with clinical deterioration and increased mortality among COVID-19 patients [3,7,11,12]. Moreover, the concerns about the cardiac involvement in COVID-19 is further complicated by the fact that drugs commonly used in severe COVID-19 cases (i.e. chloroquine/hydroxychloroquine, azithromycin, lopinavir/ritonavir, protease inhibitors, fluoroquinolones) have a cardio-toxic QT prolonging potential themselves and may cause and exacerbate cardiac failure, arrhythmia or other cardiovascular disorders [3,13,14]. Being amongst the official treatments used in COVID-19 patients in our county, the combination of azithromycin and chloroquine or hydroxychloroquine is considered to be particularly associated with increased likelihood of precipitating the cardiac dysrhythmias [14].

The heart rate variability (HRV) analysis, providing data on the modulation of the sympathetic and parasympathetic branches of the autonomic nervous system (ANS), is a readily available noninvasive tool being utilized for decades to evaluate general well-being in various clinical settings $[15,16]$ and has been associated with the infection and immune system function in several medical conditions [17-21].

The main mechanism underlying the cardiac manifestations of COVID-19 is considered the virusdependent alteration of hypothalamic pituitary axis functions with subsequent development of autonomic dysfunction [4]. Accordingly, the HRV analysis has become increasingly recognized tool enabling a noninvasive measure of autonomic function in COVID-19 patients, which may also facilitate identification of at the risk of developing cardiovascular complications and provide early warning of impending cytokine storm and earlier recognition of clinical deterioration [4,21].

In fact, certain HRV parameters has been suggested to predict the severity and mortality in critically ill patients with COVID-19 as well as to be related to levels of proinflammatory cytokines, such as IL-6, CRP, and procalcitonin [7].

No study to date has addressed the HRV parameters in COVID-19 patients in Turkey. This retrospective observational study aimed to investigate the HRV indices in hospitalized patients with suspected or confirmed diagnosis of COVID-19 in comparison to healthy controls and in relation to proinflammatory cytokines (CRP, D-Dimer, ferritin and procalcitonin).

\section{Materials and Methods \\ 2.1. Study population}


A total of 95 patients hospitalized with confirmed $(n=53)$ or suspected $(n=42)$ diagnosis of COVID-19 and 20 healthy control subjects were included in this retrospective observational study conducted at a tertiary care cardiology clinic. The confirmed COVID-19 cases were patients with laboratory confirmation of SARS$\mathrm{CoV}-2$ positivity on first or repeated real-time reverse transcription-polymerase chain reaction (RT-PCR) test. Suspected COVID-19 cases were those with findings suggestive of COVID-19 pneumonia on lung computed tomography (CT) but with a negative RT-PCR test. Adult ( $\geq 18$ years of age) patients with lung CT imaging or RTPCR analysis based diagnosis of COVID-19 who had 24$\mathrm{h}$ Holter monitoring during their hospitalization were included in the study.

Written informed consent was obtained from each subject following a detailed explanation of the objectives and protocol of the study which was conducted in accordance with the ethical principles stated in the "Declaration of Helsinki" and approved by the institutional ethics committee.

\subsection{Assessments}

Data on patient demographics (age, gender), comorbid diseases and proinflammatory cytokines (CRP, D-Dimer, ferritin, procalcitonin) were recorded in suspected COVID-19 and confirmed COVID-19 groups, while the 24-h Holter monitoring parameters (on $3^{\text {rd }}$ day of hospitalization) were recorded in suspected and confirmed COVID-19 groups as well as in the control group.

\subsection{4-h Holter monitoring and HRV analysis}

The ECG parameters included sinus rhythm (SR), atrial fibrillation count (AF), heart rate (HR, bpm), corrected QT interval (QTc), T-peak to T-end intervals (Tpe), ventricular extrasystoles (VES), supraventricular ectopy (SVE), supraventricular tachycardia (SVT) and paroxysmal atrial fibrillation (PAF) episodes.

The time-domain HRV indices included SDNN (the SD of all NN intervals, ms), SDNNI (SDNN index, the mean of the 5-minute SD of NN intervals 5 minutes calculated over 24 hours, ms), SDANN (The SD of the average NN intervals, measured for 5-minute recording, ms), RMSSD (The root mean square of successive $\mathrm{NN}$ intervals, ms),
NN50 count (number of pairs of adjacent NN intervals differing by more than 50 milliseconds), pNN50 (percentage of pairs of adjacent $\mathrm{NN}$ intervals differing by more than 50 milliseconds, \%) and HRV triangular index (total NN intervals number/height of the histogram of all $\mathrm{NN}$ intervals).

The frequency-domain HRV indices included LF (low frequency power, $\mathrm{ms}^{2}$ ), $\mathrm{HF}$ (high frequency power, $\mathrm{ms}^{2}$ ) and the $\mathrm{LF} / \mathrm{HF}$ ratio. The heart rate turbulence indices included turbulence onset (TO, \%) and turbulence slop (TS, ms/beat).

\subsection{Treatments}

All patients diagnosed with COVID-19 were treated with hydroxychloroquine sulfate (a loading dose of 2x400 mg tablet followed by $2 \times 200 \mathrm{mg}$ tablet for 5 days) and/or favipiravir (2 x $1600 \mathrm{mg}$ loading, 2 x $600 \mathrm{mg}$ maintenance for 5 days) and/or azithromycin (500 mg tablet, on the first day and $250 \mathrm{mg} /$ day for the following 4 days) in accordance with the official COVID-19 Adult Treatment Algorithm guidance established by Republic of Turkey Ministry of Health [22].

\subsection{Statistical analysis}

Statistical analysis was made using IBM SPSS Statistics for Windows, version 23.0 (IBM Corp., Armonk, NY). Pearson Chi-square $(\chi 2)$ test and Fisher's exact test were used for the comparison of categorical data. MannWhitney U test, independent sample t-test, ANOVA or Kruskal-Wallis test (with Dunn's post-hoc test) were used for the numerical variables. Data were expressed as "mean \pm standard deviation (SD), median (min-max) and percent $(\%)$ where appropriate. $\mathrm{p}<0.05$ was considered statistically significant.

\section{Results and Discussion}

\subsection{Results}

3.1.1.Baseline characteristics and inflammatory markers No significant difference was noted between suspected COVID-19 and confirmed COVID-19 groups in terms of age $($ mean \pm SD $53.6 \pm 18.6$ vs. $51.0 \pm 13.1$ years, respectively), gender (females: 42.9 vs. 39.6\%, respectively) and the comorbid diseases (hypertension in 21.4 vs. $26.4 \%$, respectively) (Table 1 ).

Table 1. Baseline characteristics and pro-inflammatory cytokines in COVID-19 groups

\begin{tabular}{|c|c|c|c|}
\hline & Suspected COVID-19 $(n=42)$ & Confirmed COVID-19 $(n=53)$ & p value \\
\hline \multicolumn{4}{|l|}{ Patient demographics } \\
\hline Age (years), mean \pm SD & $53.6 \pm 18.6$ & $51.0 \pm 13.1$ & 0.444 \\
\hline Gender (female), $\mathrm{n}(\%)$ & $18(42.9)$ & $21(39.6)$ & 0.750 \\
\hline \multicolumn{4}{|l|}{ Comorbidities, n(\%) } \\
\hline Hypertension & $9(21.4)$ & $14(26.4)$ & 0.573 \\
\hline Diabetes & $7(16.7)$ & $10(18.9)$ & 0.781 \\
\hline Coronary artery disease & $2(4.8)$ & $7(13.2)$ & 0.163 \\
\hline Chronic heart failure & $5(11.9)$ & $2(3.8)$ & 0.235 \\
\hline Chronic kidney failure & $3(7.1)$ & $3(5.7)$ & 1.000 \\
\hline \multicolumn{4}{|c|}{ Proinflammatory cytokines, median (min-max) } \\
\hline $\mathrm{CRP}(\mathrm{mg} / \mathrm{L})$ & $33.8(0.2-264)$ & $23.2(0.2-195)$ & 0.188 \\
\hline D Dimer $(\mu \mathrm{g} / \mathrm{mL})$ & $0.56(0.15-141)$ & $0.31(0.16-8.94)$ & 0.214 \\
\hline Procalcitonin (ng/mL) & $0.07(0.2-15.20)$ & $0.07(0.02-0.40)$ & 0.235 \\
\hline Ferritin $(\mu \mathrm{g} / \mathrm{L})$ & $185.0(4.72-952.0)$ & $212.0(5.76-1704.0)$ & 0.183 \\
\hline
\end{tabular}


CRP, D-dimer, procalcitonin and ferritin levels were also similar between suspected and confirmed cases of COVID-19 (Table 1). In-hospital mortality did not occur in any of COVID-19 patients and all were discharged with full recovery.

3.1.2. 24-h Holter monitoring findings in study groups
No significant difference was noted between control, suspected COVID-19 and confirmed COVID-19 groups in terms of HR, SDNNI (ms), pNN50 (\%), TO (\%) and TS (ms/beat). None of the Holter monitoring parameters differed significantly between patients with suspected COVID-19 and those with confirmed COVID-19 (Table 2).

Table 2. 24-h Holter monitoring findings on ECG, HRV and HR turbulence indices in COVID-19 and control groups

\begin{tabular}{|c|c|c|c|c|c|c|c|}
\hline \multirow[b]{2}{*}{ mean \pm SD } & \multirow[b]{2}{*}{$\begin{array}{l}\text { Control } \\
(\mathbf{n}=20)(A)\end{array}$} & \multirow{2}{*}{$\begin{array}{l}\text { Suspected } \\
\text { COVID-19 } \\
(\mathrm{n}=42)(B)\end{array}$} & \multirow{2}{*}{$\begin{array}{c}\text { Confirmed COVID- } \\
19 \\
(\mathrm{n}=53)(\mathrm{C}) \\
\end{array}$} & \multirow[b]{2}{*}{$p$ value } & \multicolumn{3}{|c|}{ Post-Hoc p value } \\
\hline & & & & & A vs. B & A vs. $\mathrm{C}$ & $\begin{array}{c}\text { B vs. } \\
\text { C }\end{array}$ \\
\hline \multicolumn{8}{|l|}{ ECG parameters } \\
\hline HR-max (bpm) & $121.35 \pm 30.13$ & $127.40 \pm 18.21$ & $115 \pm 12.50$ & 0.080 & - & - & - \\
\hline HR-min (bpm) & $54.05 \pm 5.97$ & $61.24 \pm 13.04$ & $57.58 \pm 11.71$ & 0.068 & - & - & - \\
\hline QTc & - & $452.64 \pm 18.59$ & $457.55 \pm 18.65$ & 0.206 & - & - & - \\
\hline Tpe & - & $83.76 \pm 14.19$ & $87.89 \pm 14.41$ & 0.169 & - & - & - \\
\hline Number of VES & $14.50 \pm 127.75$ & $0 \pm 2.25$ & $1 \pm 7.75$ & 0.019 & 0.005 & 0.094 & 0.345 \\
\hline Number of SVE & $27.50 \pm 7.65$ & $0 \pm 1.25$ & $0 \pm 5.25$ & 0.001 & $<0.001$ & 0.001 & 0.531 \\
\hline Number of SVT & $0 \pm 0.9$ & 0 & 0 & 0.076 & - & - & - \\
\hline Number of PAF episodes & - & 0 & 0 & 0.868 & - & - & - \\
\hline \multicolumn{8}{|l|}{$\begin{array}{l}\text { HRV, time-domain } \\
\text { indices of }\end{array}$} \\
\hline SDNN (ms) & $134.40 \pm 30.15$ & $99.98 \pm 27.29$ & $94 \pm 23$ & $<0.001$ & $<0.001$ & $<0.001$ & 0.803 \\
\hline SDNNI ( ms) & $36.55 \pm 16.42$ & $25 \pm 15.50$ & $21 \pm 9.75$ & 0.060 & - & - & - \\
\hline SDANN (ms) & $116.75 \pm 28.11$ & $81.17 \pm 26.50$ & $81 \pm 18$ & $<0.001$ & $<0.001$ & $<0.001$ & 0.937 \\
\hline RMSSD (ms) & $51.50 \pm 23.04$ & $11871 \pm 11674$ & $12334 \pm 8860.25$ & $<0.001$ & $<0.001$ & $<0.001$ & 0.584 \\
\hline NN50 count & $\begin{array}{c}9890.50 \pm \\
5168.54\end{array}$ & $2962 \pm 5134.25$ & $2307 \pm 2851.25$ & 0.004 & 0.004 & 0.002 & 0.851 \\
\hline pNN50 (\%) & $8 \pm 7$ & $3 \pm 8$ & $3 \pm 5.5$ & 0.056 & - & - & - \\
\hline HRV triangular index & $30.05 \pm 7.54$ & $19.49 \pm 6.01$ & $20 \pm 5.5$ & $<0.001$ & $<0.001$ & 0.001 & 0.423 \\
\hline \multicolumn{8}{|l|}{$\begin{array}{l}\text { HRV, frequency- } \\
\text { domain indices }\end{array}$} \\
\hline $\mathrm{LF}\left(\mathrm{ms}^{2}\right)$ & $15.16 \pm 7.25$ & $57.42 \pm 38 . .99$ & $56.80 \pm 23.65$ & $<0.001$ & 0.001 & $<0.001$ & 0.561 \\
\hline $\mathrm{HF}\left(\mathrm{ms}^{2}\right)$ & $72.77 \pm 6.8$ & $18.36 \pm 15.73$ & $20.47 \pm 14.19$ & $<0.001$ & $<0.001$ & $<0.001$ & 0.566 \\
\hline LF/HF ratio & $0.19 \pm 0.14$ & $2.16 \pm 3.79$ & $2.18 \pm 2.90$ & $<0.001$ & $<0.001$ & $<0.001$ & 0.742 \\
\hline \multicolumn{8}{|l|}{ HR turbulence indices } \\
\hline TO $(\%)$ & $0 \pm 0.01$ & $-0.01 \pm 0.02$ & $-0.02 \pm 0.02$ & 0.130 & - & - & - \\
\hline TS (ms/beat) & $2.05 \pm 5.87$ & $6.51 \pm 6.41$ & $5.88 \pm 2.64$ & 0.226 & - & - & - \\
\hline
\end{tabular}

SR: Sinus rhythm count; AF: Atrial fibrillation; HR: Heart rate; QTc: corrected QT interval; Tpe: T-peak to T-end intervals; VES: Ventricular extrasystoles; SVE: Supraventricular ectopy; SVT: Supraventricular tachycardia; PAF: Paroxysmal atrial fibrillation (PAF) episodes; SDNN SD of all NN intervals; SDNNI: SDNN index; SDANN: SD of the average NN intervals; RMSSD: Root mean square of successive NN intervals; NN50: Pairs of adjacent NN intervals differing by more than 50 milliseconds; pNN50: percentage of NN50; LF: Low frequency power; HF: High frequency power; TO: Turbulence onset; TS: Turbulence slop

The number of SVE $(27.50 \pm 7.65$ vs. $0 \pm 1.25$ and $0 \pm$ $5.25, \mathrm{p}<0.001$ and $\mathrm{p}=0.001$, respectively) in both suspected and confirmed COVID 19 groups, while the number of VES values $(14.50 \pm 127.75 \mathrm{vs} .0 \pm 2.25$, $\mathrm{p}=0.005)$ in the suspected COVID-19 group were significantly lower than the values in the control group (Table 2).

For the time-domain HRV indices, in both suspected COVID-19 and confirmed COVID-19 groups, SDNN $(134.40 \pm 30.15$ vs.99.98 \pm 27.29 and $94 \pm 23 \mathrm{~ms}$, respectively, $\mathrm{p}<0.001$ for each), SDANN (116.75 \pm 28.11 vs. $81.17 \pm 26.50$ and $81 \pm 18 \mathrm{~ms}$, respectively, $\mathrm{p}<0.001$ for each), NN50 count (9890.50 \pm 5168.54 vs. $2962 \pm$ 5134.25 and $2307 \pm 2851.25, p=0.004$ and $p=0.002$, respectively) and HRV triangular index (30.05 $\pm 7.54 \mathrm{vs}$. $19.49 \pm 6.01$ and $20 \pm 5.5$, respectively, $\mathrm{p}<0.001$ for each) values were significantly lower, whereas RMSSD values $(51.50 \pm 23.04$ vs. $11871 \pm 11674$ and $12334 \pm 8860.25$ ms, $\mathrm{p}<0.001$ for each) were significantly higher than the values in the control group (Table 2)

For the frequency-domain indices, in both suspected COVID-19 and confirmed COVID-19 groups, HF (72.77 \pm 6.8 vs. $18.36 \pm 15.73$ and $20.47 \pm 14.19 \mathrm{~ms}^{2}$, respectively, $\mathrm{p}<0.001$ for each) values were significantly lower, whereas LF $(15.16 \pm 7.25$ vs. $57.42 \pm 38 . .99$ and $56.80 \pm 23.65 \mathrm{~ms}^{2}, \mathrm{p}=0.001$ and $\mathrm{p}<0.001$, respectively) and $\mathrm{LF} / \mathrm{HF}$ ratio $(0.19 \pm 0.14$ vs. $2.16 \pm 3.79$ and $2.18 \pm$ 2.90 , respectively, $\mathrm{p}<0.001$ for each) values were significantly higher than the values in the control group (Table 2)

3.1.3. Correlation between proinflammatory cytokines and HRV parameters

Other than significant positive correlation between procalcitonin and SDNN values $(r=0.227, p=0.044)$, no correlation of CRP, D-dimer, procalcitonin or ferritin was noted with HRV parameters (Table 3). 
Table 3. Correlation between proinflammatory cytokines and HRV parameters

\begin{tabular}{llcccccc}
\hline & & \multicolumn{3}{c}{ Time-domain HRV indices } & \multicolumn{3}{c}{ Frequency-domain HRV indices } \\
& & SDNN & RMSSD & Triangular index & LF & HF & LF/HF ratio \\
\hline \multirow{3}{*}{ CRP } & $\mathrm{r}$ & -.055 & -.058 & -.172 & -.156 & .052 & -.143 \\
& $\mathrm{p}$ & .592 & .572 & .094 & .131 & .615 & .166 \\
& $\mathrm{~N}$ & 95 & 95 & 95 & 95 & 95 & 95 \\
D-dimer & $\mathrm{r}$ & -.082 & -.070 & -.052 & -.015 & -.012 & -.047 \\
& $\mathrm{p}$ & .429 & .498 & .615 & .886 & .907 & .653 \\
\multirow{5}{*}{ Procalcitonin } & $\mathrm{N}$ & 95 & 95 & 95 & 94 & 94 & 94 \\
& $\mathrm{r}$ & .227 & .019 & -.107 & -.136 & -.092 & -.045 \\
& $\mathrm{p}$ &. $\mathbf{0 4 4}$ & .871 & .346 & .234 & .423 & .695 \\
Ferritin & $\mathrm{N}$ & 79 & 79 & 79 & 78 & 78 & 78 \\
& $\mathrm{r}$ & -.091 & -.039 & -.142 & .086 & -.084 & -.044 \\
& $\mathrm{p}$ & .401 & .719 & .188 & .433 & .443 & .684 \\
\hline
\end{tabular}

SDNN: SD of all NN intervals; RMSSD: Root mean square of successive NN intervals; LF: Low frequency power; HF: High frequency power Pearson Correlation analysis, r: correlation coefficient

\subsection{Discussion}

Our findings revealed no significant difference in the time-domain (SDNN, SDNNI, SDANN, RMSSD, pNN 50, triangular index) or frequency-domain (LF, HF, $\mathrm{LF} / \mathrm{HF}$ ratio) $\mathrm{HRV}$ indices as well as in HR turbulence parameters (TO and TS) between the suspected and confirmed COVID-19 cases. Both the time-domain (lower SDNN, SDANN and triangular index and higher RMSSD) and frequency-domain (higher LF, lower HF and higher $\mathrm{LF} / \mathrm{HF}$ ratio) $\mathrm{HRV}$ indices significantly differed in suspected and confirmed COVID-19 groups when compared to the control group.

Based on the time-domain indices, our findings revealed the lower SDNN (reflecting overall HRV), lower HRV triangular index (reflecting overall HRV without requiring detailed beat-by-beat scanning), lower SDANN (reflecting total circadian rhythms and physical activity) and higher RMSSD (reflecting PNS activity) in the suspected and confirmed COVID-19 patients than in control subjects. Accordingly, our findings indicate similar heart rate and lower HRV and circadian parameters of HRV along with higher PNS activity in COVID-19 patients. Indeed, the HRV recordings obtained in the suspected and confirmed COVID-19 patients in the current study are in accordance with the cut-off values of 24-h measures of HRV defined for the moderately depressed HRV (SDNN < $100 \mathrm{~ms}$ and HRV triangular index <20) [23]. The identification of a depressed HRV and a depressed triangular index in our COVID-19 patients seems important given that both parameters are considered to predict mortality and arrhythmic complications independent of other recognized risk factors [23,24].

In the current study, the time-domain HRV indices indicated low autonomic nervous system activity (i.e. low SDNN), and a predominance of the parasympathetic system (high RMSSD) due to sympathetic depletion, while frequency-domain HRV indices indicated low vagal activity (low $\mathrm{HF}$ ) and high sympathetic activity (high LF) with increase in $\mathrm{LF} / \mathrm{HF}$ ratio, indicating presence of a sympathovagal modulation mediated ANS dysfunction in COVID-19 patients. These findings seem to suggest the varying influence of the different stages of COVID-19 disease on autonomic dysregulation with the severe inflammatory system response syndrome (SIRS) and the CARS [7].

Notably, in a case control study in 63 COVID-19 infected patients and 43 healthy controls, the authors reported an increase in the time domain measures (SDNN and RMSSD) and decrease in the frequency domain measures (HF and LF) in COVID-19 patients compared to controls with similar LF/HF ratios between the groups, emphasizing the association of COVID-19 infection with increased parasympathetic activity [4]. However, in a single-center, prospective, observational pilot study in 14 critically ill COVID-19 patients on mechanical ventilation, the authors reported that a low autonomic nervous system activity (i.e. low SDNN) and a predominance of the parasympathetic system and a proportionally greater vagal activity (i.e. high HF) due to a depletion of sympathetic activity in COVID-19 patients were associated with a worse prognosis, higher mortality, and higher IL-6 levels [7].

Hence, our findings emphasize the consideration of HRV as a tool to measure fluctuations in autonomic inputs to the heart rather than the mean level of autonomic inputs, suggesting that the both autonomic withdrawal and a sufficiently high level of sympathetic input may lead to reduced HRV [23,25]. Accordingly, the overall HRV findings in the current study seem to support the consideration of depressed HRV not to be a simple reflection of the sympathetic overdrive and/or vagal withdrawal due to poor ventricular performance but also to reflect depressed vagal activity which has a strong 
association with the pathogenesis of ventricular arrhythmias and sudden cardiac death [23]. In addition, LF has also been suggested to reflect both sympathetic and vagal activity rather than sympathetic modulations per se and thus the $\mathrm{LF} / \mathrm{HF}$ ratio reflects the sympatho/vagal balance or sympathetic modulations [23]. Notably, in a study on the usefulness of regular HRV testing for monitoring health status in general population during the COVID-19 lockdown, the authors reported decreased RMSSD and $\mathrm{HF}$ and increased resting heart rate in $80 \%$ of population, as indicators of poor cardiovascular health, while in $20 \%$ of the participants the lockdown was positively rated, as shown by an improved well-being and parasympathetic activity (increased RMSSD) [20].

Indeed, the decrease in SNDD along with increase in RMSSD in our COVID-19 patients support the significant autonomic dysregulation and a decreased activity of the ANS with increase in the parasympathetic activity as a reflection of the compensatory response to depletion of sympathetic activity reported in in patients with COVID-19 and critically ill patients [7,26]. Nonetheless, it should be noted that changes in frequency-domain HRV indices in hospitalized COVID19 patients may differ from those observed in other critically ill patient populations (i.e. those with sepsis or myocardial infarction), that include also a lower HRV (SDNN) but a decreased sympathovagal balance with a reduction of the sympathetic component (LF) and a predominance of the parasympathetic component (HF), as predicting the increased risk of developing multiple organ dysfunction syndromes (MODS) and mortality in case of ARDS in critically ill patients [7,27-31].

Given that the vagally driven cholinergic antiinflammatory pathway (CAP) inhibits the nuclear factor $\kappa \mathrm{B}(\mathrm{NF}-\kappa \mathrm{B})$, which is the transcriptional factor of proinflammatory cytokines, a well-balanced cytokine release is considered to depend on adequate vagal signaling [32]. Besides, the coronaviruses also replicate using NF- $\kappa \mathrm{B}$ transcriptional factor by inducing unrestricted NF- $\kappa \mathrm{B}$ expression accelerating both, virus replication and cytokine transcription [32]. Hence, CAP detriment due to depressed vagal tone is considered critical in predicting the severity of COVID-19 [32], while the pharmacological and electrical activation of the CAP, through non-invasive brain neuromodulation and vagus nerve stimulation (VNS), is considered a promising therapeutic strategy to enable sympathovagal balance in severe courses of COVID-19 [7,9,32-36].

In fact, the increase in RMSSD (reflecting parasympathetic activity) in COVID-19 patients in the current study seems also notable given the consideration of RMSSD as an HRV measure sensitive to the inflammatory processes in viral infection [19]. Nonetheless, no significant difference was noted in any of HRV indices including RMSSD between suspected and confirmed cases of COVID-19 in our study, indicating no influence of PCR confirmed viral load on COVID-19 dependent alterations in HRV.
In addition, QTc interval, one of the main manifestations of cardiac autonomic neuropathy [24], was also similar in suspected and confirmed cases of COVID-19, and the average values were $>440 \mathrm{~ms}$ indicating "borderline QT prolongation" [37] in both groups, possibly reflecting the potential cardiotoxicity of hydroxychloroquine and azithromycin treatments used in both groups [13]. Chloroquine and azithromycin are independently associated with an increased risk of QTc prolongation and subsequent severe arrhythmias and death, while their combination may further potentiate this risk [38-41].

In a systematic review and network meta-analysis on the comparative efficacy and safety of pharmacological interventions for the treatment of COVID-19, the authors reported that a combination of hydroxychloroquine and azithromycin was associated with increased QT prolongation incidence and fatal cardiac complications (torsades de pointes, cardiac arrest, and severe ventricular arrhythmia) in cardiac-impaired populations [13]. Hence, the similar changes in HRV parameters in suspected and confirmed COVID-19 groups, irrespective of PCR-confirmed viral load, in the current study may also reflect the potential cardiotoxicity of hydroxychloroquine and azithromycin treatments received by both suspected and confirmed COVID-19 patients. Hence, strict monitoring should be implemented in all patients receiving these treatments to maintain a tolerable safety margin [13].

Nonetheless, our findings revealed no significant difference between the control, suspected COVID-19 and confirmed COVID-19 groups in terms of TO and TS, which are considered to be predictors of cardiac autonomic activity and mortality [24].

In a meta-analysis of 51 studies in 2238 patients, the authors concluded that HRV spectral analysis serves to monitor the autonomic activity that controls inflammatory processes in humans [42]. They have also noted a strong association among inflammatory parameters (mainly IL-6 and CRP) with a higher HF and a low SDNN [42]. Similarly, the studies in COVID-19 patients also revealed the association of decrease in HRV (SDNN) with elevated CRP [21), the positive correlation of HF values with IL-6 values [7] and no correlation of SDNN with IL-6, procalcitonin or CRP [7]. Notably, our findings revealed no correlation of the CRP, D-dimer, ferritin, procalcitonin with time-domain or frequency domain indices of HRV, apart from a significant positive correlation between procalcitonin and SDNN values. Hence, amongst the proinflammatory cytokines suggested to be related to HRV and thus prognosis in COVID-19 patients, only procalcitonin seems to be associated with low SDNN values in the current study.

Certain limitations to this study should be considered. First, potential lack of generalizability is an important limitation due to single-center design with relatively small sample size. Second, inability to assess the impact of COVID-19 per se on HRV without concomitant treatments for ethical reasons, seems to be another limitation of the present study 


\section{Conclusion}

In conclusion, representing the first retrospective reallife observational study on HRV among COVID-19 patients in Turkey, our findings revealed significant changes in both time-domain and frequency-domain indices of HRV in COVID-19 patients, regardless of the viral load, in favor of ANS dysfunction. Specifically, time-domain measures indicated depressed HRV (low SDNN and low triangular index) and a predominance of the parasympathetic system (high RMSSD) due to sympathetic depletion, while frequency-domain indices indicates low vagal activity (low HF) and high sympathetic activity (high LF) with increase in LF/HF ratio (sympathovagal modulation) in COVID-19 patients as compared with control subjects. Apart from procalcitonin, none of the proinflammatory cytokines correlated with HRV (SDNN). Accordingly, our findings indicate the potential utility of $\mathrm{HRV}$ as a valuable clinical tool to monitor autonomic dysfunction in COVID-19 patients resulting from the underlying inflammatory process or the treatment-related toxicities, aiding clinicians in early prediction of a cytokine storm, and in the triage, disease progress monitoring and treatment. In addition, given the suggested role of sympathetic/parasympathetic imbalance in disease prognosis, the non-invasive neuromodulation techniques to maintain the balance between the components of ANS might be used as a therapeutic strategy in critically ill patients with COVID-19.

\section{Acknowledgements and Disclosures}

The authors declare that they have no conflict of interest. No funding received.

\section{References}

1.Perlman, S, Another decade, another coronavirus. The New England journal of medicine, 2020, 382(8), 760-762.

2. Wang, L, Wang, Y, Ye, D, Liu, Q, Review of the 2019 novel coronavirus (SARS-CoV-2) based on current evidence, International journal of antimicrobial agents, 2020, 55(6), 105948.

3. Kwenandar, F, Japar, K.V, Damay, V, Hariyanto, T.I, Tanaka, M, Lugito, N.P.H, et al., Coronavirus disease 2019 and cardiovascular system: A narrative review, International Journal of Cardiology. Heart \& Vasculature, 2020, 29, 100557.

4. Kaliyaperumal, D, R.k, K, Alagesan, M, Ramalingam, S, Characterization of cardiac autonomic function in COVID-19 using heart rate variability: a hospital based preliminary observational study, Journal of Basic and Clinical Physiology and Pharmacology, 2021, 32(3), 247-253.

5. Huang, C, Wang, Y, Li, X, Ren, L, Zhao, J, Hu, Y, Clinical features of patients infected with 2019 novel coronavirus in Wuhan, China, Lancet (London, England), 2020, 395(10223), 497-506.

6.Xu, Z, Shi, L, Wang, Y, Zhang, J, Huang, L, Zhang, C, et al., Pathological findings of COVID-19 associated with acute respiratory distress syndrome, The Lancet. Respiratory medicine, 2020, 8(4) 420-422.

7. Aragón-Benedí, C, Oliver-Forniés, P, Galluccio, F, Yamak Altinpulluk, E, Ergonenc, T, El Sayed Allam, A, et al., Is the heart rate variability monitoring using the analgesia nociception index a predictor of illness severity and mortality in critically ill patients with COVID-19? A pilot study, PLoS One, 2021, 16(3), e0249128.

8. Gattinoni, L, Chiumello, D, Caironi, P, Busana, M, Romitti, F, Brazzi, L, et al., COVID-19 pneumonia: different respiratory treatments for different phenotypes?, Intensive Care Medicine, 2020 46(6), 1099-1102.
9.Pavlov, V.A, Tracey, K.J, Neural regulation of immunity: molecular mechanisms and clinical translation, Nature Neuroscience, 2017, 20(2), 156-166.

10. Tufan, A, Avanoğlu Guler, A, Matucci-Cerinic, M, COVID-19, immune system response, hyperinflammation and repurposing antirheumatic drugs, Turkish Journal of Medical Sciences, 2020, 50(SI-1), 620-632.

11. Guo, T, Fan, Y, Chen, M, Wu, X, Zhang, L, He, T, et al., Cardiovascular Implications of Fatal Outcomes of Patients With Coronavirus Disease 2019 (COVID-19), JAMA cardiology, 2020, 5(7), 811-818.

12. Lazzerini, P.E, Boutjdir, M, Capecchi, P.L., COVID-19, Arrhythmic Risk, and Inflammation: Mind the Gap!, Circulation, 2020, 142(1), 7-9.

13. Kim, M.S, An, M.H, Kim, W.J, Hwang, T.H, Comparative efficacy and safety of pharmacological interventions for the treatment of COVID-19: A systematic review and network meta-analysis, PLoS Medicine, 2020, 17(12), e1003501.

14. Chary, M.A, Barbuto, A.F, Izadmehr, S, Hayes, B.D, Burns, M.M, COVID-19: Therapeutics and Their Toxicities, Journal of Medical Toxicology : Official Journal of the American College of Medical Toxicology, 2020, 16(3), 284-294.

15. Thayer, J.F, Yamamoto, S.S, Brosschot, J.F, The relationship of autonomic imbalance, heart rate variability and cardiovascular disease risk factors, International Journal of Cardiology, 2010, 141, 122-131.

16. Shaffer, F, Ginsberg J.P, An overview of heart rate variability metrics and norms, Frontiers in Public Health, 2017, 5, 528.

17. Fairchild, D, Predictive monitoring for early detection of sepsis in neonatal ICU patients, Current Opinion in Pediatrics, 2013, 25, 172 179.

18. Pavlov, V.A, Chavan, S.S, Tracey, K.J, Bioelectronic medicine: from preclinical studies on the inflammatory reflex to new approaches in disease diagnosis and treatment, Cold Spring Harbor Perspectives in Medicine, 2020, 10, a034140.

19. Drury, R.L, Jarczok, M, Owens, A, Thayer, J.F, Wireless Heart Rate Variability in Assessing Community COVID-19, Frontiers in Neuroscience, 2021, 15, 564159.

20. Bourdillon, N, Yazdani, S, Schmitt, L, Millet, G.P, Effects of COVID-19 lockdown on heart rate variability, PLoS One. 2020, 15(11), e0242303.

21. Hasty, F, García, G, Dávila, C.H, Wittels, S.H, Hendricks, S, Chong, S, Heart Rate Variability as a Possible Predictive Marker for Acute Inflammatory Response in COVID-19 Patients, Military Medicine, 2020, 186(1-2), e34-E38.

22. The Turkish Ministry of Health, Guidelines for the Management of Adults with COVID-19. https://covid19bilgi.saglik.gov.tr/depo/rehberler/COVID-

19_Rehberi.pdf, 2020 (accessed 18.04.2021)

23. Heart rate variability. Standards of measurement, physiological interpretation, and clinical use. Task Force of the European Society of Cardiology and the North American Society of Pacing and Electrophysiology, European Heart Journal, 1996, 17(3), 354-381.

24. Behbahani, S, Shahram, F, Electrocardiogram and heart rate variability assessment in patients with common autoimmune diseases: a methodological review, Turk Kardiyoloji Dernegi Arsivi : Turk Kardiyoloji Derneginin yayin organidir, 2020, 48(3), 312-327.

25. Malik, M, Camm, A.J, Components of heart rate variability -- What they really mean and what we really measure, The American Journal of Cardiology, 1993, 72, 821-822.

26. Das, G, Mukherjee, N, Ghosh, S, Neurological Insights of COVID19 Pandemic, ACS chemical neuroscience, 2020, 11(9), 1206-1209.

27. Ahmad, S, Ramsay, T, Huebsch, L, Flanagan, S, McDiarmid, S, Batkin, I, et al., Continuous multi-parameter heart rate variability analysis heralds onset of sepsis in adults, PLoS One, 2009, 4(8), e6642.

28. Chen, W.L, Chen, J.H, Huang, C.C, Kuo, C.D, Huang, C.I, Lee, L.S, Heart rate variability measures as predictors of in-hospital mortality in ED patients with sepsis, The American Journal of Emergency Medicine, 2008, 26(4), 395-401.

29. Pontet, J, Contreras, P, Curbelo, A, Medina, J, Noveri, S, Bentancourt, $\mathrm{S}$, et al., Heart rate variability as early marker of multiple organ dysfunction syndrome in septic patients, Journal of Critical Care, 2003; 18(3):156-163.

30. Chen, W.L, Tsai, T.H, Huang, C.C, Chen, J.H, Kuo, C.D. Heart rate variability predicts short-term outcome for successfully resuscitated 
patients with out-of-hospital cardiac arrest, Resuscitation, 2009, 80(10), 1114-1118

31. Chen, I.C, Kor, C.T, Lin, C.H, Kuo, J, Tsai, J.Z, Ko, W.J, et al., Highfrequency power of heart rate variability can predict the outcome of thoracic surgical patients with acute respiratory distress syndrome on admission to the intensive care unit: a prospective, single-centric, case-controlled study, BMC Anesthesiology, 2018, 18(1), 34

32. Leitzke, M, Stefanovic, D, Meyer, J.J, Schimpf, S, Schönknecht, P. Autonomic balance determines the severity of COVID-19 courses, Bioelectronic Medicine, 2020, 6(1), 22.

33. Tracey, K.J. The inflammatory reflex, Nature, 2002, 420(6917), 853859.

34. Pavlov, V.A, Wang, H, Czura, C.J, Friedman, S.G, Tracey, K.J. The cholinergic anti-inflammatory pathway: a missing link in neuroimmunomodulation, Molecular Medicine (Cambridge, Mass.), 2003, 9(5-8), 125-134

35. Baptista, A.F, Baltar, A, Okano, A.H, Moreira, A, Campos, A.C.P, Fernandes, A.M, et al., Applications of non-invasive neuromodulation for the management of disorders related to covid19, Frontiers in Neurology, 2020, 11, 573718.

36. Farsalinos, K, Niaura, R, Le Houezec, J, Barbouni, A, Tsatsakis, A Kouretas, D, et al., Editorial: Nicotine and SARS-CoV-2: COVID-19 may be a disease of the nicotinic cholinergic system, Toxicology Reports, 2020, 7:, 658-663.

37. Johnson, J.N, Ackerman, M.J, QTc: how long is too long?, British Journal of Sports Sedicine, 2009, 43(9), 657-662.

38. Woosley, R, Heise, C, Romero, K, QTdrugs list. https://www.crediblemeds.org/., 2020 (accessed 20.05.2021)

39. Vouri, S.M, Thai, T.N, Winterstein, A.G, An evaluation of co-use of chloroquine or hydroxychloroquine plus azithromycin on cardiac outcomes: A pharmacoepidemiological study to inform use during the COVID19 pandemic, Research in Social \& Administrative Pharmacy: RSAP, 2021, 17(1), 2012-2017.

40. Chatre, C, Roubille, F, Vernhet, H, Jorgensen, C, Pers, Y.M, Cardiac Complications Attributed to Chloroquine and Hydroxychloroquine: A Systematic Review of the Literature, Drug Safety, 2018, 41(10), 919-931.

41. Ozturk, T, Gurpinar, T, Balaban, C.I, Tuncok, Y, Potentia interactions between increased cytokines in COVID-19 and drugs used to treat COVID-19, Celal Bayar Üniversitesi Sağlık Bilimleri Enstitüsü Dergisi, 2021, 8(1), 174-185.

42. Williams, D.P, Koenig, J, Carnevali, L, Sgoifo A, Jarczok MN Sternberg EM, et al., Heart rate variability and inflammation: A metaanalysis of human studies, Brain, Behavior, and Immunity, 2019, 80, 219-226

http://edergi.cbu.edu.tr/ojs/index.php/cbusbed isimli yazarın CBU-SBED başlıklı eseri bu Creative Commons Alıntı-Gayriticari4.0 Uluslararası Lisansı ile lisanslanmıștır. 